\title{
TV/Series
}

Hors séries 1 | 2016

Lost: (re)garder l'île

\section{The End of Lost: The Paradox of Serialized Television and the Experience of Loss}

\section{Hugo Clémot}

Translator. Chloe Farrell

\section{OpenEdition \\ Journals}

\section{Electronic version}

URL: http://journals.openedition.org/tvseries/4952

DOI: 10.4000/tvseries.4952

ISSN: 2266-0909

\section{Publisher}

GRIC - Groupe de recherche Identités et Cultures

\section{Electronic reference}

Hugo Clémot, «The End of Lost: The Paradox of Serialized Television and the Experience of Loss », TV/ Series [Online], Hors séries 1 | 2016, Online since 01 December 2020, connection on 05 December 2020. URL : http://journals.openedition.org/tvseries/4952 ; DOI : https://doi.org/10.4000/tvseries. 4952

This text was automatically generated on 5 December 2020

\section{(c) (†) $\ominus$}

TV/Series est mis à disposition selon les termes de la licence Creative Commons Attribution - Pas d'Utilisation Commerciale - Pas de Modification 4.0 International 


\title{
The End of Lost: The Paradox of Serialized Television and the Experience of Loss
}

\author{
Hugo Clémot \\ Translation : Chloe Farrell
}

1 The ending of Lost was one of the greatest disappointments in the history of serialized television-so much so that it is used as a reference point when discussing series with disappointing endings. ${ }^{1}$ The question of why so many members of its audience were disappointed by the ending poses the conceptual problem of narrative closure-in other words, the difficulty of explaining that which provokes the impression of finality the audience expects to feel when watching visual media. In the following pages, I will use Lost as a basis to discuss this subject, which has been widely debated in contemporary philosophy of cinema since the American philosopher Noël Carroll suggested the "erotetic" model as a means of resolving the debate. Convinced of the insufficiency of this theory, I present a "teleologic" model opposing his theory by raising a problem I propose to call "the series-following paradox." As I conceive it, the resolution to this paradox requires the adoption of a new approach to television series, which additionally allows us to recognize that-from a certain perspective-the ending of Lost is successful.

\section{The Problem of Narrative Closure: Erotetic and Teleologic Models}

\section{The Carollian Analysis of Narrative Closure}

2 In a series of articles begun in $1984^{2}$, the analytic philosopher Noël Carroll proposed an "erotetic" narrative model to understand cinematic narrative closure. This conception holds that the impression of finality ${ }^{3}$ or resolution that we feel at the end of the majority of films is evoked by the fact that the questions raised by the film for the 
audience are answered. This need for a response to our questions and the pleasure that we derive from them-and thus from narratives as well-is part of human nature.

Using a causalist conception of narrative as a starting point, according to which a discourse is a narrative if-and only if-it describes at least two temporal events linked by causality ${ }^{4}$, Carroll introduces the erotetic model with the intention of responding to the following objection: If the narrative has a narrative connection ${ }^{5}$ that relates to its fundamental elements-in other words, a causal relationship between events-how do we account for the impression of closure we feel when all of the questions raised by the narrative have been answered, since the mere fact of observing a succession of causal relationships doesn't appear to be sufficient to move us? Where does this feeling come from? According the the erotetic model of the interrogative relationship used by Poudovkine ${ }^{6}$, the sensation of closure results from the fulfilment of a natural need to find answers to our questions. Narrators make use of this need by recounting events in such a way that the audience asks certain questions-with varying levels of awarenessto then receive answers ${ }^{7}$, even if it means manipulating temporality ${ }^{8}$. The use of flashbacks and flash forwards is, of course, one of the most important formal elements of Lost ${ }^{9}$. For example, in the episode that features Sawyer (S1E8), the audience is invited to ask why his character is so malicious, a question whose response is supplied by the flashbacks. It is because he himself was victim of someone malicious-a conman who he will ultimately imitate, going so far as to take on his identity. The erotetic model also allows us to understand how the episodes situated in different seasons function together to maintain the audience's attention. Does episode S2E10 ("The 23rd Psalm") thus aim to answer the question raised in episode S1E19 ("Deus ex machina") of what the Nigerian drug traffickers disguised as preachers were doing in the small plane that crashed on the island? This model rewards the attention to detail of discerning audience members: In episode S2E15, an answer to the question of why Sawyer is wearing new glasses is given-a question which, of course, was prepared two episodes earlier when Sawyer explains to Kate that he lost is old glasses on the lifeboat.

Figure 1: Sawyer in S2E13

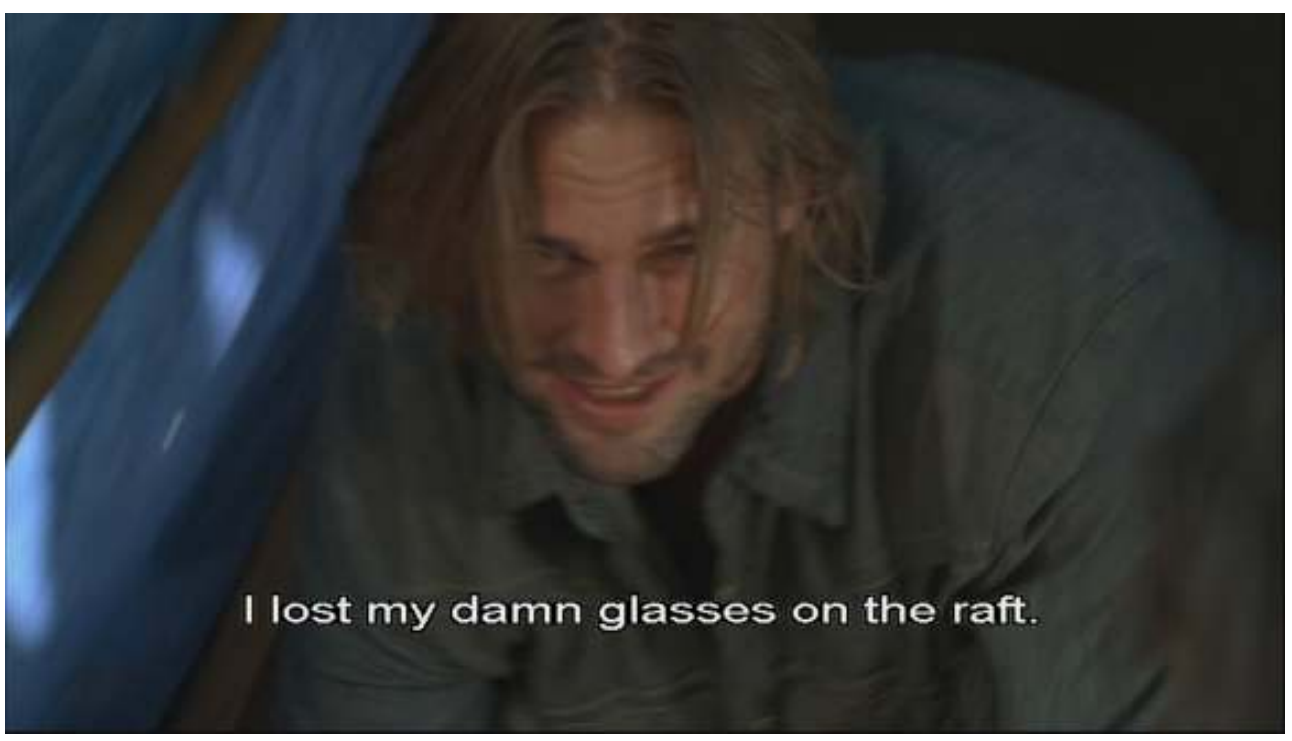




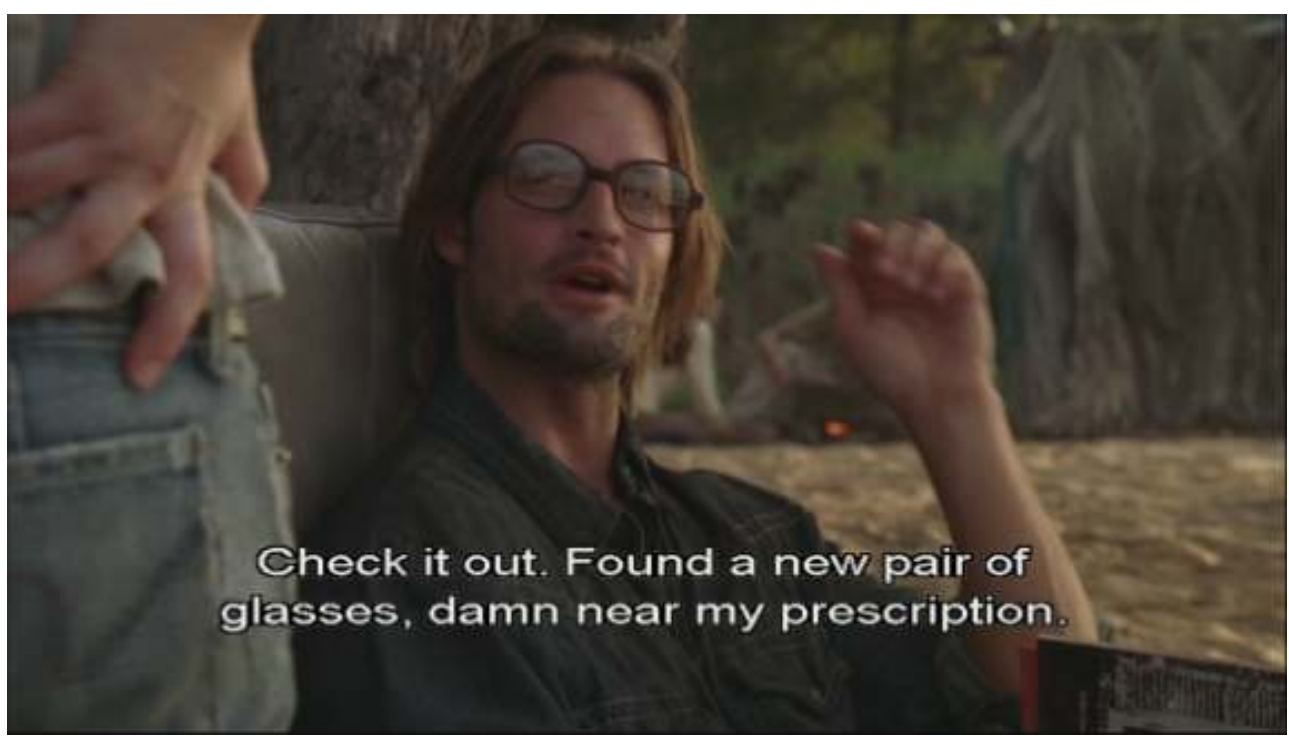

To illustrate this definition of narrative closure, Carroll provides a counter example. In Noah Baumbach's 2005 film The Squid and the Whale, the director places special emphasis on the alcoholic tendencies of one of his characters, the younger brother Frank. The question of what will happen to him, and especially what consequences his "problem" will have on the story, will be left unanswered. Carroll points out that in certain cases, this absence of closure provokes annoyance in the audience, an annoyance that stems from the implicit promise made to the audience to give them all the answers to the questions raised-a promise that is ultimately broken ${ }^{10}$. This seems similar to the way in which the audience experienced the ending of Lost. Early on, this experience is described by Hugo Reyes, known as "Hurley"-the character who often represents the audience's position. In episode S1E18 ("Numbers"), he brings up various questions that have gone unanswered since the beginning of the show, before vehemently asking Danielle Rousseau to explain the meaning of the maddening string of numbers ${ }^{11}$.

Figure 3: Hurley in S1E18

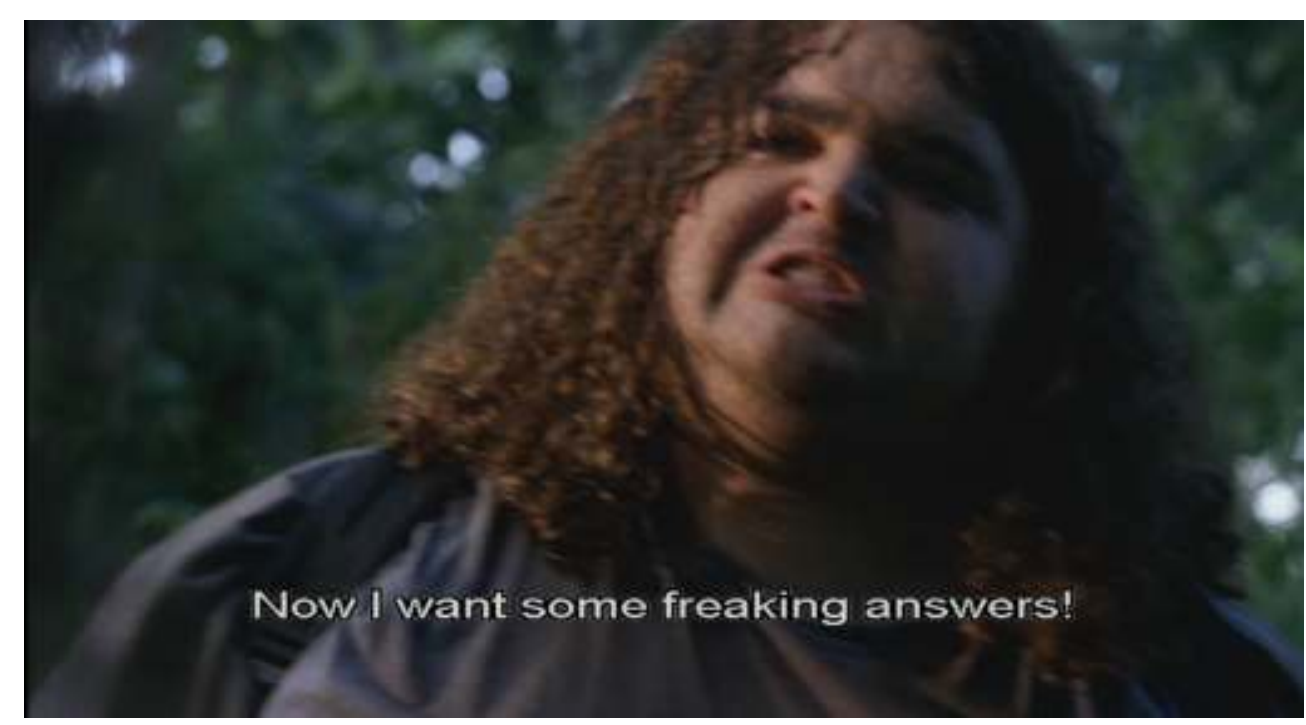


Carroll maintains that finality is not present in the narrative, rather it is an impression that arises when the psychic tension, which creates the search for answers to questions raised by the narrative, is released-a tension that itself is born from the natural need for answers to our questions. If we are to believe this theory, the show Lost would be a disappointment because it would have been unable to respond to all of the questions that it raised in the audience's minds. The promise-implicit or explicit-of a resolution would not have been kept, the audience's attention would not have paid off, and their disappointment would have been legitimate.

\section{Is Narrative Closure a Mere Impression?}

6 It is possible to critique a presupposition characteristic of Carroll and other analytic film philosophers such as David Velleman ${ }^{12}$. Indeed, both Carroll and Velleman state that narrative closure is an emotion born from the satisfaction of a natural need, whether it be to find the answers to our questions or to release the emotional pressure established in the beginning of a story. For example, we find a direct reference to this naturalist theory in episode S1E8 of the show Dollhouse (Joss Whedon, 2009-2010), when Dr. Saunders/Whiskey explains that, "Each Active's brain was programmed to release a sedative the moment they felt closure." Yet, is referencing a natural need sufficient to explain this impression of finality? Indeed, if we understand that the mind demands certain responses, we are less likely to think that it requires responses to all questions; for example, "What does 'Rosebud' in Citizen Kane (directed by Orson Welles, 1941) mean?" would be on the same plane as, "What do the numbers 4814152342 in Lost mean?" as would, "Why is the panther in The Pink Panther (directed by Blake Edwards, 1963) pink? ${ }^{13 "}$ or "Why aren't there more snakes on the island in Lost?" or even "Why were there so many blue tarps in the plane in Lost?" which leads us to no longer understand why Carroll is frustrated because a film does not explain what happens to a prepubescent secondary character with alcoholic tendencies, ${ }^{14}$ when Carroll is not frustrated by not knowing exactly how many children the hero had (who, as we are told at the end, lives happily ever after). It is as if we were to say that it is frustrating not to know what happened to that blond character present at Boone's funeral in S1E21, but that it is not frustrating not to know what all of the secondary characters are doing at any given moment. 
Figures $4 a$ and $4 b$ : The Group of Survivors in S1E21
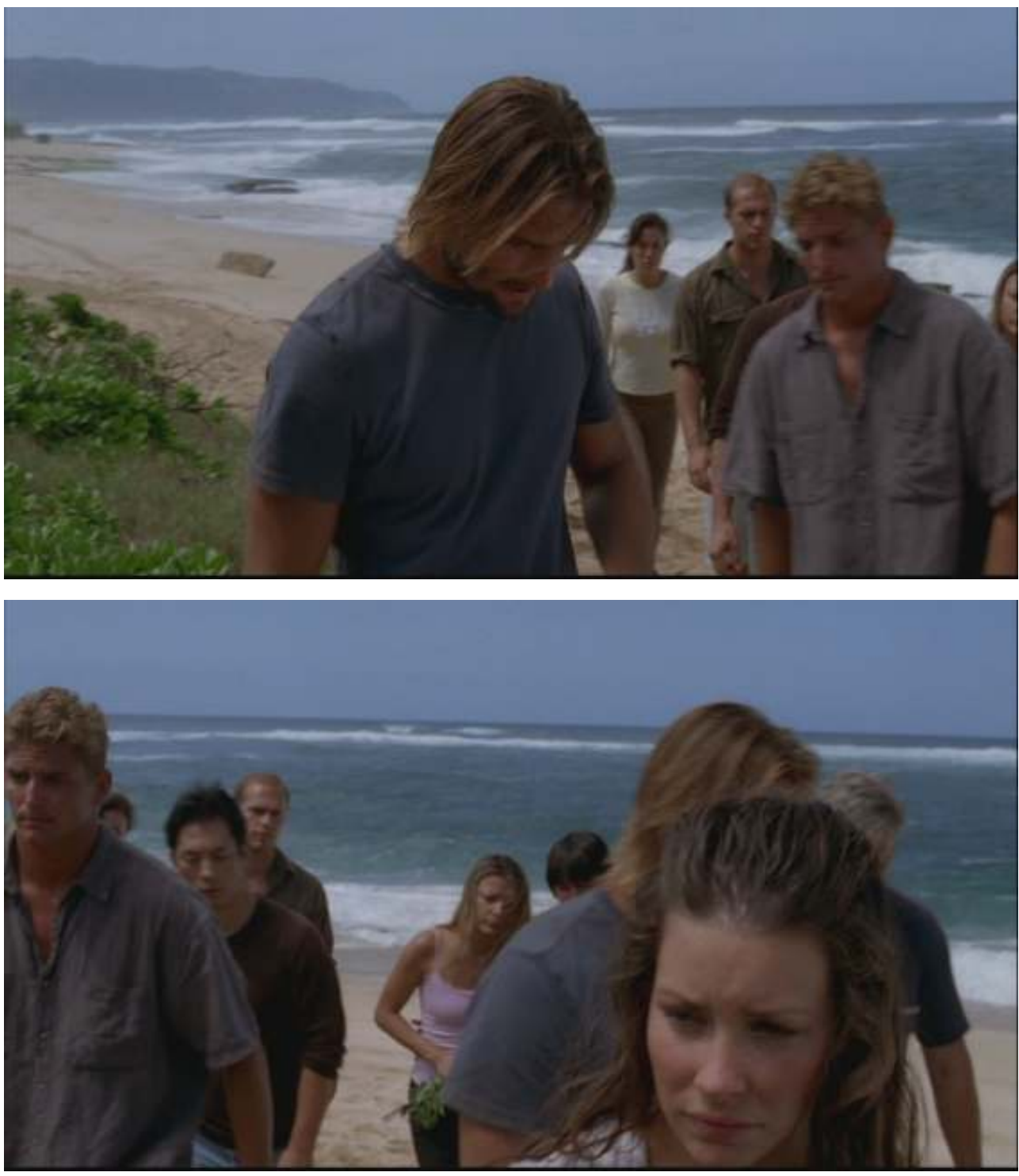

7 The idea is not that one is obliged to be frustrated, because this would be both absurd and foolish-as foolish as gesticulating when holding a stick of dynamite-but rather that there must be something that allows the audience to know how to ask the right questions. Carroll claims to account for the phenomenon of the frustration felt when a question raised by a narrative is not answered when he talks about an "implicit promise ${ }^{151}$ made by the director to reward our attention by supplying all of the information necessary to respond to the questions the film generates for us.

But as each image of a film could arouse an infinite number of questions in the mind of each viewer, this explanation does not seem to be sufficient. For example, in the scene in which the survivors of the plane crash agree to entrust Kate with the gun ${ }^{16}$ (S1E3), the close-up on the revolver could raise different questions in the minds of various audience members, who would not receive a response as time goes on ("What brand is this revolver?" "Where was it purchased?" "Who produced it?" "Why is it that color?" "Has it been well cleaned?" etc.) In other words, the concept of narrative closure may be explained only through a natural need for answers to our questions insofar as it is important to know what questions narratives cause us to ask and what sort of 
responses are satisfying. To avoid the absurd conclusion according to which the impression of closure always occurs randomly-in other words, when the audience spontaneously stumbles upon the right questions-the model must be completed by specifying identification criteria for the relevant questions.

It can be argued that if there is indeed an experience that corresponds to the final phase of the narrative and to its ending, and that can be viewed as having resulted from an answer that was given-it is a symptom and not a criterion for narrative closure itself. Indeed, we can postulate that the criteria that permit us spontaneously to identify the relevant questions to follow the narrative is teleologic: A question deserves to be asked if it pertains to an action that we can identify as the accomplishment of a goal or an ending (in Greek, telos) - or the means of achieving a goal that motivated one of the main characters. For example, a general teleologic explanation of Lost could manifest in the following way: In order to save the world, the heart of the island must be protected; to protect the heart of the island, there must be a guardian; for there to be a good guardian, they must have the right attributes (know and care for the island and pass a certain number of tests); for them to have the right profile, one must look to their past; for them to know and care for the island and have passed a certain number of tests, they must be brought to the island; for them to come to the island, the plane must crash on the island; etc.

We notice that this teleological explanation is none other than Jacob's practical reasoning, meaning that we can piece it together after having seen the show. As in Aristotle's analysis ${ }^{17}$, the initial premise introduces a goal-an end for the actor-while the following premises present different means to attain this end, potentially linked by a teleological relationship from the middle to the end, until arriving at a conclusion that is the concrete action to be carried out. From this perspective, narrative closure is not exterior to the story insofar as it will be a psychological impression felt by the audience, but rather an essential narrative moment to which others are subject.

\section{Erotetic and Teleologic Models of the Impression of Narrative Closure}

11 The strength of Carroll's intuition on the erotetic model lies in having illustrated that the structure of stories can often be uncovered by investigating which questions and which answers were raised throughout the narrative ${ }^{18}$. The importance of this intuition is still relevant, even if it must be backed up by taking into account the role played by causal forces and teleology in our conception of the narrative. Indeed, the questions that the narrative raises are often the expression, in the form of a question, of the natural and intentional power of individuals-in other words, the propensities that we attribute to individuals. Thus, when a single man and and a single woman meet for the first time, such as with Jack and Kate, we wonder if they could fall in love. When, in episode S01E24, Claire's son Aaron is kidnapped, we wonder if he will be set free. In episodes S1E24-25, when we are aware of the explosive power of nitroglycerin and the combustible nature of the wick on the stick of dynamite, we can anticipate the course of events, which encourages us to ask the typically erotetic question: Will Hurleytrying as he is to extinguish the wick-prevent the dynamite's explosion, or will there be a blast that will offer a way into the hatch? 
12 The teleologic analysis that we apply in a more or less spontaneous manner to the show's events allows us to ask this question and to apply the erotetic model to the analysis of its narrative. It is because we are aware of the power and the natural or intentional goals of the characters that we are not surprised by their behavior, or-as the case may be-we successfully overcome this surprise to incorporate it into a teleologic framework that is larger than that with which we began. Our expectations are based on, as Carroll notes, "...our sense of what is possible, given earlier events. ${ }^{19 "}$ Yet this sense is more generally linked to the capacity for practical or causal reasoning that the judge, doctor, and mechanic must demonstrate.

If this conception is correct, we can account for the desire for narrative closure in the following way: If we accept that we must follow the chain of events that leads up to the final result and wait to hear the ending, it is because we want to understand. Yet we are able to understand when we reference the actions of a character, or what means they used to achieve their goals. In other words, we come to understand when we are able to produce a causal or practical line of reasoning on demand that describes the chain of events by noting both the necessary and sufficient means to produce the desired result.

The fact that the erotetic model is just one example of the teleologic theory seems to prove that we are able to grasp the impression of resolution more completely when we define it as the emotions that accompany a narrative that appears to be complete, rather than as the emotion evoked by the fact that all of our questions are answered. Indeed, it is possible that certain questions remain without answers but that we nevertheless have the impression of finality-on the condition that this lack of response does not prevent us from reconstructing the characters' practical reasoning. Indeed, in this instance we are able to understand the actions of the characters as so many means toward their various ends. It could therefore be the case that we lose the impression of finality if some of our questions are not answered. Yet we would have this impression only if it proved impossible to sort hierarchically at least some of their actions described to us in a teleologic manner. From this perspective, we can argue that the show is successful ${ }^{20}$, if we agree to believe in the finality of the narrative. Nevertheless, it could prove impossible to identify why we find watching the ending of a film or show pleasurable in such an abstract manner without using the concrete experience of a particular work as our basis. Yet when we take interest in what the series Lost has to say concerning the question of teleology, we notice that it presents a particularly pertinent discourse that shows a detailed understanding of the stakes and complexity of the problem.

Indeed, as Pacome Thiellement illustrates ${ }^{21}$, the primary opposition between Jack Shephard and John Locke is also one that exists between two types of Lost fans. As Locke says in the second half of episode S1E25, he and Jack "...don't see eye-to-eye sometimes." According to Locke, Jack is a "man of science," convinced that what happens to them happens by chance, that fighting for survival is necessary without there being necessarily the hope of achieving some sort of closure. Locke, however, is a man of faith, convinced that they have a "purpose" that could explain why the plane crashed, why they survived, etc. It is tempting-as Pacome Thiellement noted in his talk at the Forum des images-to interpret this scene as being intended to put Lost's audience on their guard. They would be obligated to choose between two strict choices: "either to accept everything, or to reject everything... To accept to take a leap of faith or not... To believe in a mythical dimension of existence or in a pure, disenchanted 
realism. ${ }^{221}$ When it comes to narrative closure, it is also tempting to double down on this opposition between reason and faith, science and religion, absurdity and sense, and the opposition between erotetic (naturalist) and teleologic (finalist) conceptions of closure.

In Lost, it is not only Hurley who is a proponent of this naturalist conception of the sensation of finality. The doctor Jack Shephard also adopts this perspective when speaking to Juliet (S03E07, "Not in Portland"): "After everything that I have been put through, you owe me an answer." Jack is thus a partisan of the naturalist explanation of the impression of finality, whereas Locke would argue that the true impression comes from the perception of an authentic finality. Nevertheless, the repeated reversal of perspectives, i.e., Locke's loss of faith when Jack converts to his point of view, leads one to believe all the more that the show is marked by modern skepticism-in other words, by the problem of having to make choices in a time of urgency and uncertainty.

\section{Orienting Oneself When One is Lost: Lost and the Experience of Loss}

\section{The Figure of the Traveler Lost in the Forest and the Skepticism of the Character, Contemporary Human Beings, and the Audience}

17 The figure of the traveler lost in the forest observed in S1E11 is, at least since Descartes, the figure of the individual confronted with practical skepticism-obligated (as Pascal writes, we are "embarked") to make urgent choices without knowing with certainty which ones are $\operatorname{right}^{23}$. For example, we find this figure in many of today's films and shows about zombies in which the hero-fleeing infected cities-finds refuge in areas deemed uninhabited. We can see in this an artistic "paraphrase" of our contemporary skepticism, which is to say, our difficulty in understanding a world full of disasters and danger and to know how to act to protect ourselves from danger ${ }^{24}$. These various literary, cinematographic, and televisual references also illustrate that which sociological studies on audience reaction confirm time and time again: Audiences of fictional narratives find ways of reflecting on their own existence and day-to-day struggles in these works. For example, in episode S5E13, Hurley analyzes Miles's relationship with his father, Pierre Chang, through the fictional example of Luke's relationship to Darth Vader in Star Wars (directed by George Lucas, 1977), confirming this work's epiphanic function in popular culture. Hurley's plan, begun in 1977, to rewrite the screenplay for The Empire Strikes Back (1980) and send it to George Lucas is thus not a futile effort. In Lost, a summation of our skepticism can be found in Kate's remark to Juliet in episode S3E15 when they are handcuffed to each other in the forest: "Welcome to the wonderful world of not knowing what the hell's going on."

This remark is also a commentary on our position as audience members-one of many reflexive moments present in the show. It indicates that in Lost, skepticism is not merely present in the characters ${ }^{25}$ themselves, nor designed to allow us to reflect on our position in the world, but it is also there-in a more interesting way-to help tame and keep at bay the audience's skepticism, as they are no longer as apt to believe the stories that are told to them. Following arthouse cinema, mainstream cinema entered, in its turn, the "era of modernist suspicion," which began in the early 1990s. In other words, it is like the moment in art history when artists could no longer rely on 
conventions and inherited genres, since viewers themselves had ceased to believe in them. The show Lost is a modernist attempt to overcome this difficulty by confronting the audience's skepticism.

Encouraged by the teleologic model of understanding, the audience's skepticism tends to be expressed in the following terms: Either it is possible to know the characters' goals and to situate each narrative element within a teleological perspective, or the narrative is devoid of meaning. But because it is impossible for a narrative to be entirely coherent and, on the other hand, it is always possible to subscribe to the belief that we merely project goals that are not actually there onto the characters and the diagetic, can we therefore believe in the narrative?

It is worth mentioning that these reflections are more or less those of Locke-which is to say, those of the character who is simultaneously the most dogmatic and who goes through a skeptic crisis with the most serious consequences when in the Pearl Dharma station in episode S2E21, he discovers that pushing the button in the hatch is merely an experiment filmed and observed by scientists. Eko attempts to rekindle Locke's faith in the island by telling him that if they press the button, it is not because they were told to do so in a film, but because they believe that they were destined to do so. The sequence is especially noteworthy for the audience because it attracts attention to their position in relation to the characters they must believe in so as to appreciate the show. Indeed, is it certain that the actions of the characters have meaning? Does the writers' work consist of variations on a theme devoid of meaning or on the same facts and the same movements of the characters-a process which would thus be the equivalent of the return to zero of the hatch's clock ${ }^{26}$ ?

\section{The "Paradox of Serialized Television" and the Aesthetic Experience}

21 Given that it presupposes we understand the meaning of a story when we are able to conceptualize the actions of the characters as a means of navigating their circumstances in order to achieve their goals, the teleologic model seems to presuppose the existence of a stable and static order of teleological relationships. In other words, a hierarchy of goals would allow us easily to identify the function of various scenes and sequences and relate them to the goals of the characters from a diagetic point of viewor from a fictional point of view-to the writer's intentions. From a fictional point of view, this model seems to line up perfectly with the idea of cinematic genre and imbue the idea of the "laws of genre" with meaning. Each cinematographic genre has various goals (to make the audience laugh, cry, etc.) that would determine, more or less thoroughly, the means of attaining them-the ways of going about things or, even more so, the rules or laws of the genre in question.

22 Nevertheless, in the twentieth century, we discovered a new skeptic paradox that highlights the fact that there is no goal that can strictly determine the means by which it may be attained. In his book Wittgenstein on Rules and Private Language: An Elementary Exposition $^{27}$, Saül Kripke maintains that he discovered the existence of a "skeptic paradox" that is "the most radical and original skeptic problem that philosophy has seen to date. ${ }^{28 "}$ It seems that this paradox is explicitly stated in paragraph 201 of Philosophical Investigations, when Wittgenstein writes: "This was our paradox: no course of action could be determined by a rule, because every course of action can be brought 
into accord with the rule. ${ }^{29 "}$ This "rule-following paradox" is sufficiently well known that it was explained by one character to another in a recent popular film, The Oxford Murders (directed by Alex de la Iglesia, 2008). For our investigation, the explanation of this idea in the film is remarkable in two respects. For one, it is said that this paradox has the power of driving people mad. Furthermore, we notice that this sequence in The oxford Murders ends with a shot that is reminiscent of another shot from Shock Corridor, a classic film on mental illness (directed by Samuel Fuller, 1963), in which a journalist passes himself off as a mental patient in order to investigate his story and ends up losing his mind during a fit, which also occurs in the hallways of a psychiatric hospital, while seated next to an individual whose body type is similar to that of Hugo Reyes.

Figure 5 : Shock Corridor (directed by Samuel Fuller, 1963)

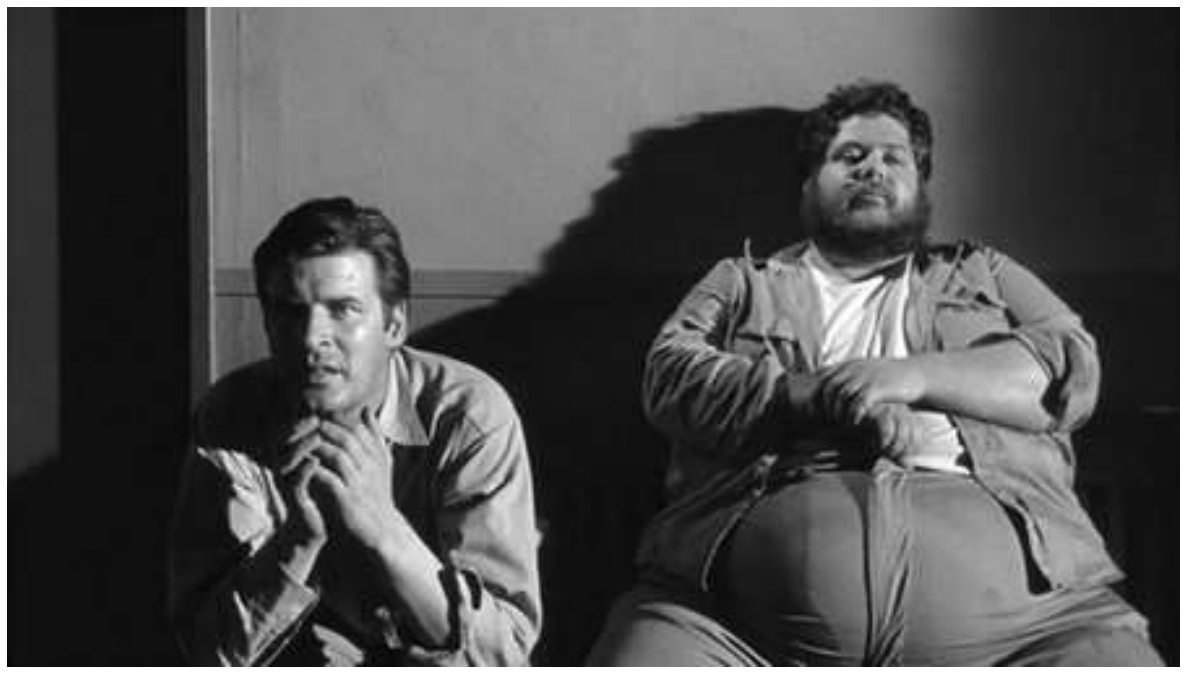

Figure 6 : Hurley without Dave in Lost S2E18

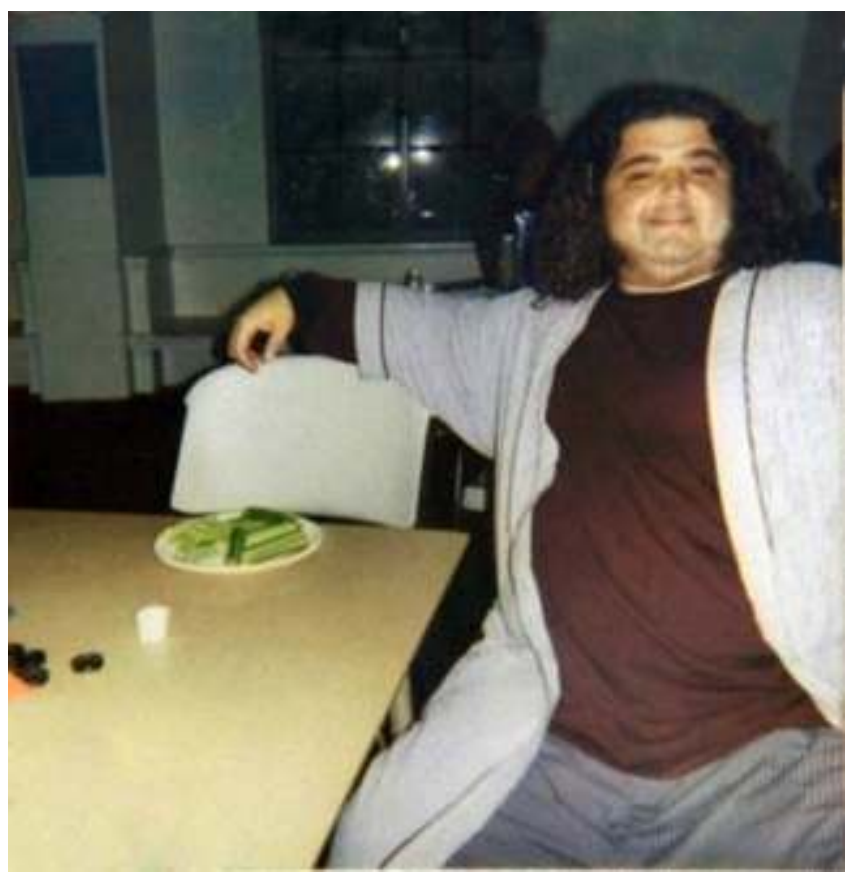



of listing a progression or even a series of numbers in order to understand their meaning; of course, we are reminded of the numbers 48151623 42. Thus, it logically still seems possible to approach a series of numbers from a different angle and thus retrospectively modify the meaning of the numbers ${ }^{30}$. Yet if we are to ask if this paradox can be applied not only to series of numbers but to television series as well-to the extent that they are composed of a sequence of events whose meaning must be determined by both past events and future events-we remark that the response is positive. It is always possible to approach a television series differently and thus retrospectively modify the meaning of the past events that constitute it, which Lost's use of flash sideways demonstrates quite well. I suggest that the name "the series paradox" be attributed to this idea whose consequences are, as I see it, important for the question of narrative closure.

ndeed, the teleologic model presupposes that we understand the meaning of a narrative if we are successful in identifying the events as the characters' means of attaining their goals. But it is always possible to approach a television series from a different angle, which means that we can never be sure of what its goals are and thus, according to the same teleologic model, that we can never be sure to understand that which is narrated to us. Yet if there is a skeptic truth in this, then it also threatens the understanding that the audience has of their own stories. Indeed, the flashbacks through which we learn about the lives of the survivors can be interpreted as formal commentary on the question of how to give meaning to one's existence. The consequence of the series paradox is that I cannot imbue meaning into my own story if I must wait to have achieved my principal goal or goals-the meaning of my existence. In other words, television series allow us to have the skeptic experience of "the series paradox," which is ultimately a televisual form of the skeptic experience of the contingency of existence ${ }^{31}$. Nevertheless, the series paradox opens up the possibility of recognizing (alongside Kate in episode S6E17) that "nothing is irreversible"-that series can allow us to become aware of that which it is still possible for us to change and to become a better version of ourselves. In this way, Roz Kaveney demonstrated the importance of the idea of personal development in shows such as Buffy the Vampire Slayer (Joss Whedon, 1997-2003), in which the figure of the shadow double proliferates, i.e., the various people you could have been under different circumstances. One thinks of the character Cordelia, the pom-pom girl, who Buffy herself was before having her powers, or the character Faith, a vampire killer with neither family nor friends, or even of the relationship between Angel and Spike ${ }^{32}$.

This idea is extremely important in Lost. In episode S1E17, Locke notes that everyone begins a new life on the island; Michael tells his son that although they experienced setbacks, they will begin again from zero, and Sun asks Jin if they can fall back in love. Elsewhere, Jacob justifies his means of selecting candidates to become the guardian of the island with the fact that it is in their best interest to be given a new opportunity to become the person that they always should have been. The "series paradox" confirms the fact that television series represent a privileged medium of expression for what Stanley Cavell calls moral perfectionism ${ }^{33}$. Nevertheless, how can one hope to imbue a television series or one's own life with meaning if "nothing is irreversible" and if one can never define a fixed ending for oneself? Does the skeptic paradox not lead us rather to "pure disenchanted realism" or the "leap of faith"? 

aesthetic experience. Indeed, that which the series allows us to experience-that which we perceive by watching it and understanding it without knowing how it will end-is that we can imbue meaning into a series or an existence by being receptive to the form that becomes apparent, without being able to get a clear picture of its ending. When watching Lost, there are at least two moments in which we note that this televisual experience of understanding is analogous with the aesthetic experience in the Kantian sense. Early on, in the scenes in which the characters are obliged to leave behind their busy, consumption-based relationships to the world to enter into the spiritual practice of contemplation ${ }^{34}$ and then later, at the end, when we are disappointed because by bringing the "harmony of imagination and understanding ${ }^{35 "}$ to an end, the series also brings the pleasure that we took from the show to an end. It reminds us of the losses in our own existence-the loss of time, the loss of companionship-which force us to find new ways of coming into contact with the world and those around us and to face the question of the condition of our own lives.

This theory relates back to the Cavellian project of an "everyday aesthetic ${ }^{36 "}$ and to the idea that works of art "... mean something to us, not just the way statements do, but the way people do. ${ }^{37 "}$ Indeed, the series offers the audience a form of skepticism and recommends a means of overcoming the experience of loss in a scene that approaches the way in which American philosophers like Emerson and Thoreau aimed to conceive of the domestication of skepticism or the inhabitation of the world. According to Stanley Cavell, "For Emerson and Thoreau you must learn to sit at home, or sit still in some attractive spot in the woods, as if to marry the world, before, if ever, you take on the burden of others. ${ }^{38 "}$ In the aforementioned scene, Locke teaches Boone how to overcome his destructive, codependent desire for Shannon and to accept the undeniable reality of their separation-or perhaps more apt-their being-separated. The same logic can be applied to Locke, Widmore, or the Dharma Initiative, when they are taken with a desire for exclusive understanding of the island's secrets ${ }^{39}$, or to Othello when he is taken with the desire to possess Desdemona body and soul. The desire for intimate and exclusive understanding of the world is deadly; the more we seek assurance regarding the presence of the world and the other, the more our object of desire escapes us and skepticism grows.

Rather than assuming it is possible to take hold of and understand the goals of the narrative's characters-without which nothing would have any meaning-what we must do, following Boone's example in this scene, is recognize the separate nature of the characters and of the world we project by admitting that we must choose to define ourselves through our reactions and our understanding, without the certainty that we are not merely projecting onto the characters goals that are not truly there. In other words, if there is a skeptic truth, there is also the fallacy that holds that the presence in the world we seek is not one that can be found through understanding. In order to regain this presence in a lost world, we must rather learn to go without understanding -to give up on knowing that the world exists and simply "accept" ${ }^{40}$ it as separate from ourselves, to give up on knowing that others exist in order to better "recognize" ${ }^{41}$ their presence by revealing ourselves to them, convinced that, "It is the thing we do not know that can save us." ${ }^{42}$

The recurring phrase in the series that signifies both that one must accept the necessity of making uncertain decisions in emergencies and that it is "the thing we do 
not know that can save us" is that of "letting go." This corresponds to the cinematographic process that consists of a forward-tracking shot, followed by a reframing with a close-up on a character's face, which allows the flashback to be introduced. This is a classic technique that uses an intuitive understanding. The Hollywood norm holds that this type of shot, called a reaction shot, represents a moment in which the interiority of the character is revealed. Yet this technique also has a more general meaning, as it expresses one of the discoveries that the show offers to its audience: The series depicts characters who are forced by the circumstances at hand to interrupt the busy flow of their lives and reflect on their lived experiences ${ }^{43}$.

\section{Overcoming Trauma Through Image: Lost or the Experience of Loss}

In his work Comment Hitchcock m'a guérit (How Hitchcock Healed Me), Serge Tisseron references a study by one of Freud's first pupils, Sándor Ferenczi, on the phenomenon of psychological "splitting." For Ferenczi, an especially violent experience of trauma can induce the personality to split in two: "...one, sensitive, which is brutally destroyed, and the other that is aware of everything, but feels nothing ${ }^{45}$." Indeed, this splitting allows the survivor to endure the experience of trauma, which can thus be "experienced" without being "felt." Nevertheless, being split in this way is to be henceforth condemned to adopt the perspective of an impartial observer on one's own existence rather than as a participant in emotionally moving events in which they are the primary person concerned-which means that one could say that they find themselves in a state of seeming life. We know that each candidate has had a traumatic experience and that this is one of the reasons Jacob chose them. Yet, the solutions put forward by Freud (remembering) or by Ferencz (finally feeling the effect of the original trauma) both describe important steps in the trajectories of the characters in the show.

31 Nevertheless, Serge Tisseron offers another solution to overcome this splitting beyond that of Freud or Ferenczi. This solution is conveyed through metaphor-in other words, through the search for words, images, or gestures that would allow those who suffer from their traumatic experiences to create their own representations of the trauma that are "sufficiently similar that they may familiarize themselves with it, but at the same time, different enough to elicit only a portion of the emotions that were felt, making it possible to delineate their limits and easily contain them. ${ }^{46 "}$

The power of metaphor is consistent with the definition offered by Jean-Pierre Esquenazi of this representation as that which occurs "...when the person involved takes ownership of their story, leading them to understand that the fictional universe represents a portion of the real world. ${ }^{47 "}$ If this similarity is correct, then Lost represents to us the part of our existences that pertains to this phenomenon of splitting, meaning that, from time to time, we have the impression that we do not lead the lives that we are meant to live in this world, of being there without being presentin short, that we miss out on our own experiences. Indeed, even if all of us have not had the misfortune of undergoing an experience of extreme trauma during the course of our lives, it is the case that the simple fact of being alive and growing old is sufficiently traumatic to make the phenomena described by Ferenczi seem strangely familiar. If we are lucky enough to live to adulthood, a fundamental experience is that of loss. Indeed, the transition from youth to adulthood is a transition from the age in which everything 
is still possible, to that in which the experience of loss reminds us of the reality of that which we have not yet lost.

In chapter 15 of The World Viewed-which constitutes an "Excursus: Some Modernist Painting," namely, Jackson Pollock's dripping lines of colored paint, Morris Louis's bands of color, Kenneth Noland's chevrons, or Frank Stella's Z formations-Cavell directs our attention toward an aspect of "'the meaning of the new fact of series, or the fact that a new medium establishes and is established by a series. ${ }^{48 "}$ That is to say that if the sorrow and the balm of adolescence is indeed the idea of infinite possibilities: "The only return on becoming adult, the only justice in forgoing that world of possibility, is the reception of actuality-the pain and balm in the truth of the only world: that it

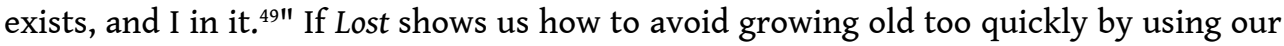
age or socioprofessional situation as a pretext to stop growing and bettering ourselves, it also teaches us to accept our age and recognize that the experience of loss itself instills value on the existences that we can lead for a little while longer in this world. In other words, reconnecting with our experience and rediscovering our emotions suggest, paradoxically, the acceptance of "letting go," while recognizing that it is the desire to preserve everything, to control one's own life in its entirety, to lose none of one's memories or relationships that destroy us and cause us suffering. Without a doubt, this is one of the lessons that the ending of Lost offers, thus allowing the audience to create their own mental representations of life's drama, which are "sufficiently close that they familiarise themselves with it, and at the same time, sufficiently distant so as to call up only part of the emotions that were felt. ${ }^{501}-$ in other words, to overcome the trauma of loss through images.

This lesson is also present in a film whose importance for Lost must not be downplayed -Jacob's Ladder (directed by Adrian Lyne, 1990), in which Jacob's friend pretends to cite Meister Eckhart in the film's central sequence:

The only thing that burns in Hell is the part of you that won't let go of life, your memories, your attachments. They burn them all away. But they're not punishing you, he said. They're freeing your soul. So, if you're frightened of dying and... you're holding on, you'll see devils tearing your life away. But if you've made your peace, then the devils are really angels, freeing you from the earth.

Figure 7: Lost S1E1

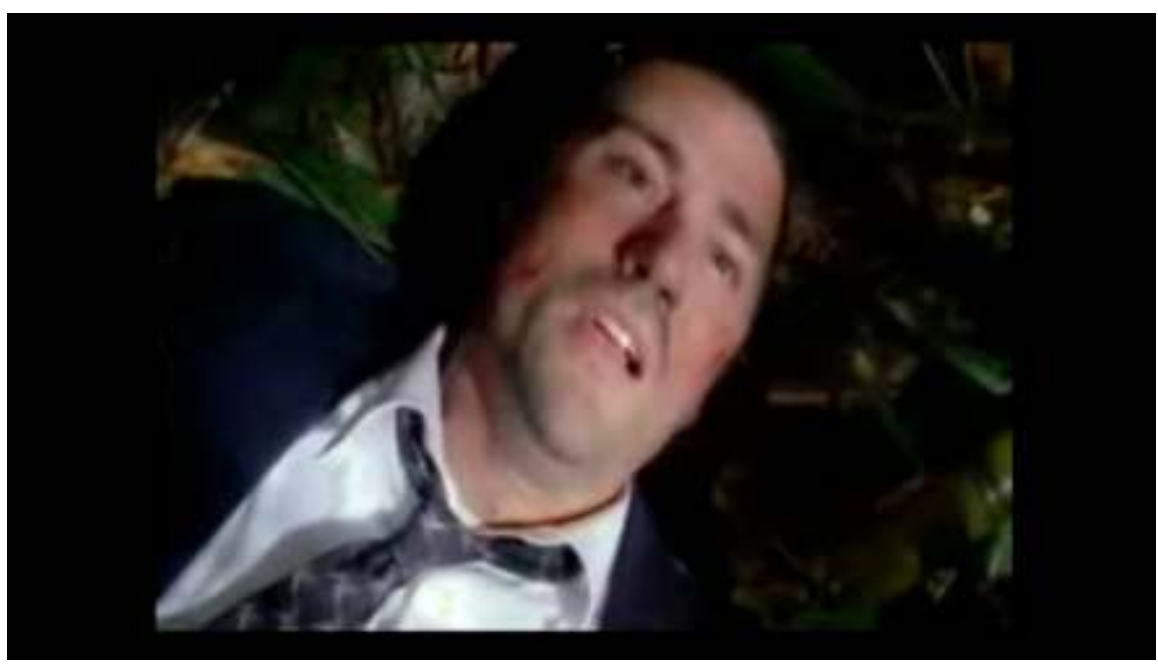


Figure 8: Jacob's Ladder

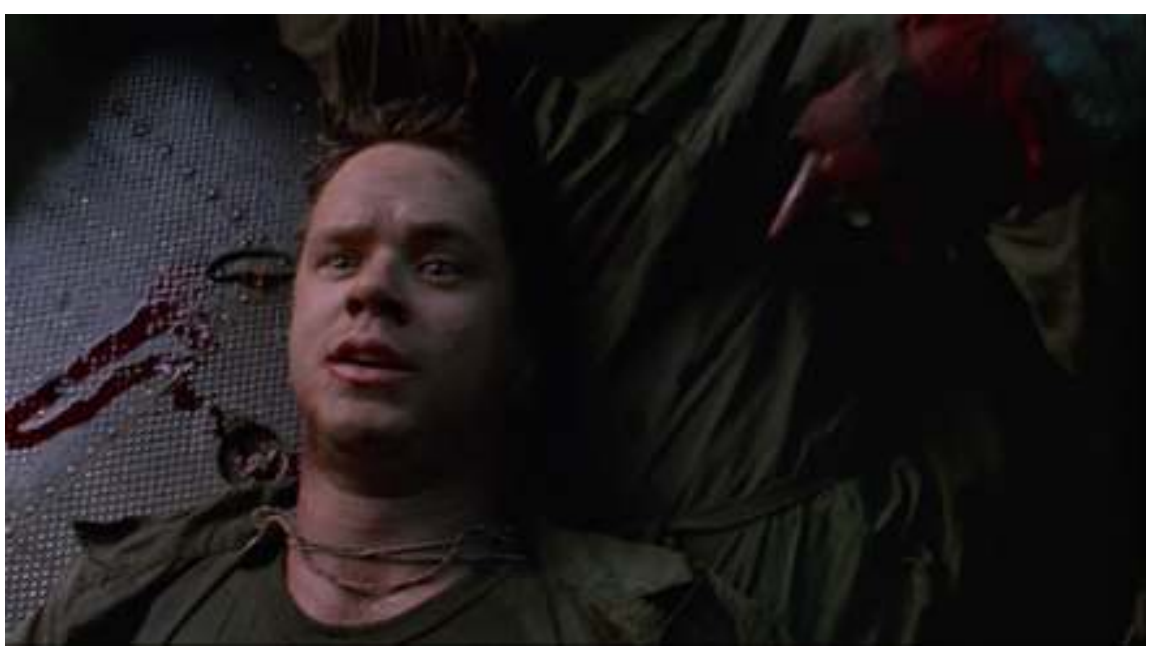

Figure 9: Lost S6E18

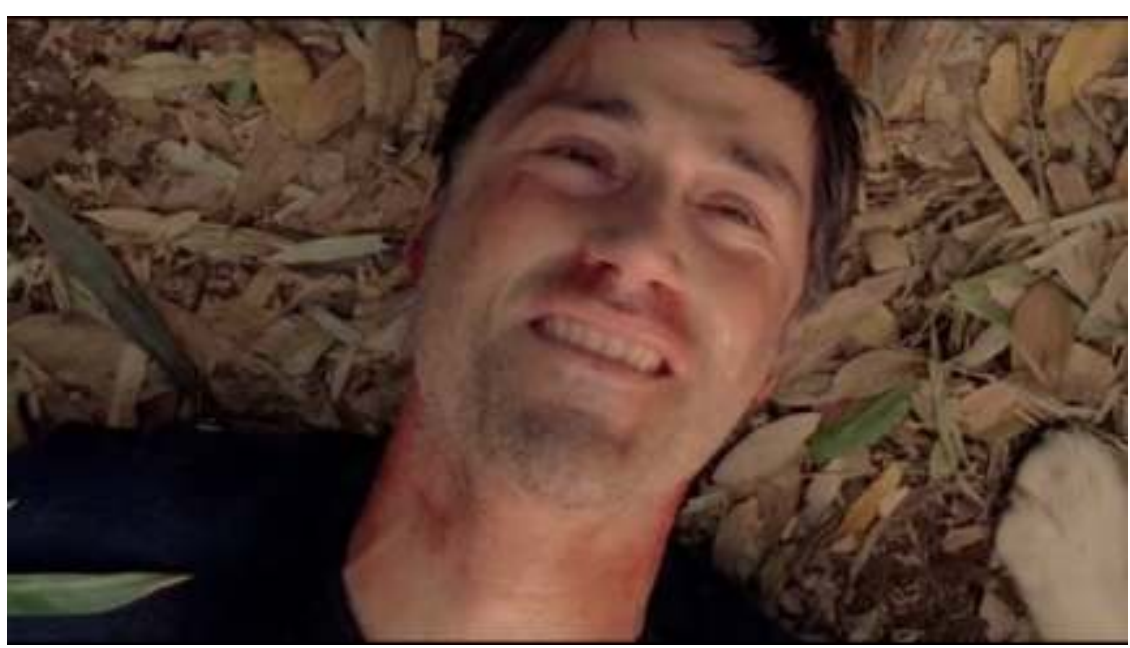

\section{Conclusion}

The scandal created by the end of the series Lost certainly raises the problem of narrative closure-in other words, the question of the knowledge that can provoke, or fail to provoke, the impression of finality that we often expect to feel when watching most audiovisual works. With Noël Carroll's erotetic-naturalist model, we come to see why the teleologic-finalist model should be favored-as it holds that we tend to have a feeling of finality when the work supplies sufficient elements to reconstruct the causal relationships between natural individuals and patients and the practical reasoning of the main characters.

Nevertheless, this model seems to presuppose the existence of a hierarchy of goals that does not withstand modern skepticism. Lost reflects upon this as well, with an idea that implies a change in philosophical approach in order to be understood. In other words, one should not philosophize about television series by adopting a top-down approach (which corresponds to what Arthur Danto taught us to critique as philosophy's subjugation of $\left.\operatorname{art}^{51}\right)$, but rather philosophize with, or even better, after television series 
-to take seriously the ideas that are expressed within them. Indeed, Lost is a series that explicitly addresses the skeptic problem of imbuing meaning into existence in the absence of teleologic necessity, an absence that is emphasized by one of the characteristics of the teleserial medium, which is to say that it is always possible to follow a televisual series in a new way, thus retrospectively modifying the meaning of the past events that constitute it. We call this "the series paradox." Yet this paradox is merely the televisual form of an ordinary skeptic experience felt by the person who becomes aware of the absence of an ultimate ending. Prone to provoke anxiety, this uncertainty when it comes to the meaning attributed to existence is also an opportunity to attain a greater sense of selfhood, provided that we know how to emulate Lost's characters when they leave behind their relationship of consumption with the world, relating to it rather through a form of contemplation. This makes them more in tune with the world's ultimate form, without being able to imagine the end. The aesthetic relationship to the ordinary aspects of the world is no longer one of understanding but of recognition, no longer a matter of knowledge but of accepting one's separation from the world and from others-a separation that is felt in the experience of loss, which is a matter of knowing how to "let go."

Far from being an insufficiency on the screenwriters' part, the absence of a satisfying resolution to end the series is instead a statement on the relationship that we must maintain with television series and with our own existences. Indeed, when we are disappointed by the ending of the show, it is not only because by giving us the slip, the series brings the pleasure that we took in watching it to an end, but more than anything, because it reminds us of our own losses and the necessity of having to find new ways of reconnecting with the world and with others-to have to reinvent the form of our own lives. In this way, the series show us that a philosophical relationship is the appropriate one to adopt in relation to it if, as Wittgenstein notes, the characteristic philosophical experience takes on the form of an "I no longer find myself"-in other words an "I am lost," in the sense that I perceive the form of a finality without being able to summon up for myself an image of the end.

\section{BIBLIOGRAPHY}

Aristotle, ed. Hugh Lawson-Tancred. Metaphysics, VII, Penguin Books, 2004.

Auerbach, David, "The Cosmology of Serialized Television," The American Reader, June 2013, http://theamericanreader.com/the-cosmology-of-serialized-television (consulted May 25, 2016).

Carroll, Noël, "Toward a Theory of Film Suspense," Persistence of Vision. The Journal of the Film Faculty of the City University of New York, \#81, 1984, pp. 65-89 ; repr. in Theorizing the Moving Picture, New York, Cambridge University Press, 1996, pp. 94-117.

"The Power of the Movies," Daedalus, vol. 1, \#14, 4, Autumn 1985, pp. 79-104; repr. in Theorizing the moving picture, pp. 78-93. 
_. "Narrative closure," Philosophical Studies: An International Journal for Philosophy in the Analytic Tradition, vol. 135, \#1, août 2007, pp. 1-15 ; repr. in The Philosophy of Moving Pictures, Malden, MA, Blackwell, 2008, chap. 5, section 2, "Cinematic Narration," pp. 133-46 ;

_-_. "Narrative closure," ed. Paisley Livingston and Carl Plantinga, The Routledge Companion to Philosophy and Film, Londres, Routledge, 2009, chap. 19, pp. 207-216;

. "Narrative closure," Art in three dimensions, chap. 17, New York, Oxford University Press, 2010, pp. 355-72.

Cavell, Stanley, "Music Discomposed," Must We Mean What We Say? A Book of Essays, Cambridge, Cambridge University Press, 1998, p. 198.

_-_. The World Viewed. Reflections on the Ontology of Film, Enlarged Edition, Cambridge, Massachusetts and London, England, Harvard University Press, 1979.

_-_. "Being Odd, Getting Even: Threats to Individuality ", Salmagundi: A Quarterely of the Humanities and Social Sciences, 67, 1985, p. 127.

Clemot, Hugo, "Une lecture des films d'horreur épidémique," Tracés, "Contagions," compiled by Florent Coste, Aurélien Robert, and Adrien Minard, \#21, 2011/2, p. 167-184, http:// traces.revues.org/5209 (consulted May 25, 2016).

_-_. La Philosophie d'après le cinéma. Une lecture de La Projection du monde de Stanley Cavell, Rennes, Presses universitaires de Rennes, 2014.

Danto, Arthur, L'assujettissement philosophique de l'art, Paris, Seuil, 1993 (1986).

Davies, Richard, "Lost in Lost's Time," The Ultimate Lost and Philosophy: Think Together, Die Alone, ed. Sharon Kaye, Hoboken, New Jersey, John Wiley \& Sons, Inc., 2011, pp. 9-31.

Esquenazi, Jean-Pierre, La vérité de la fiction, Paris, Lavoisier, 2009.

Fautrier, Pascale, "Le cinéma de Sartre," Fabula-LhT, \#2, "Ce que le cinéma fait à la littérature (et réciproquement)," December 2006, http://www.fabula.org/lht/2/fautrier.html (consulted May $25,2016)$

Ferenczi, Sándor, "Analyse d'enfants avec des adultes," Psychanalyse, t. 4, Paris, Payot, 1982 (1931).

George M. Wilson, Narration in Light, Baltimore, John Hopkins University Press, 1986, p. 50.

Hatchuel, Sarah, Lost : Fiction vitale, Paris, Presses universitaires de France, 2013.

Kant, Emmanuel, Critique of Judgement, Translated by Werner S. Pluhar, Hackett, 2010,

Kaveney, Roz, Reading the Vampire Slayer: The Complete, Unofficial Guide to Buffy and Angel, New York: I.B. Tauris, 2004

Kripke, Saül, Règles et langage privé. Introduction au paradoxe de Wittgenstein, translation T. Marchaise, Paris, Seuil, 1996 (1982).

Lang, Michelle A., "Lost: poststructural metanarrative or postmodern Bildungsroman?" (2007), LOST Thought. Leading Thinkers Discuss LOST, ed. Pearson Moore, Vancouver, Inukshuk Press, 2012, pp. 307-312.

Laugier, Sandra, "Vertus ordinaires des cultures populaires," Critique, \#776-777, January-February 2012, pp. 48-61.

Moreau, Denis, Dans le milieu d'une forêt. Essai sur Descartes et le sens de la vie, Paris, Bayard, 2012. 
Pomares, Claire, "How I Met Your Mother, pire fin de série de tous les temps ?" Les Inrocks, April 1, 2014, http://goo.gl/Rxtqvv (consulted May 25, 2016).

Poudovkine, Vsevolod I., Film Technique in Film Technique and Film Acting, New York, Grove Press, Inc., 1958.

Thiellement, Pacome, Les mêmes yeux que Lost, Paris, Léo Scheer, 2011.

Tisseron, Serge, Comment Hitchcock m'a guéri. Que cherchons-nous dans les images ?, Paris, Pluriel, 2014 (2003).

Velleman, J. David, "Narrative explanation," The Philosophical Review, vol. 112, \#1, January 2003, pp. 1-25.

Wilson, George M., Narration in Light, Baltimore, John Hopkins University Press, 1986.

Wittgenstein, Ludwig, et al. Philosophical Investigations. Translated by G.E.M. Aniscombe, 4 th ed., Wiley-Blackwell, 2010, p. 87e.

\section{NOTES}

1. See also the Les Inrocks article concerning the end of How I Met Your Mother (Carter Beys, Craig Thomas, 2005-2014) with the caption 'The Lost of Sitcoms"; Claire Pomarès, "How I Met Your Mother, pire fin de série de tous les temps ?" Les Inrocks, April 1, 2014, http://goo.gl/Rxtqvv (consulted on May 25, 2016).

2. Noël Carroll, "Toward a Theory of Film Suspense," Persistence of Vision; The Journal of the Film Faculty of the City University of New York, $\mathrm{n}^{\circ} 81,1984$, pp. 65-89; repr. in Theorizing the Moving Picture, New York, Cambridge University Press, 1996, pp. 94-117; "The Power of the Movies," Daedalus, vol.1, $\mathrm{n}^{\circ}$ 14, 4, Fall 1985, pp. 79-104; repr. in Theorizing the moving picture, pp. 78-93; "Narrative closure," Philosophical Studies: An International Journal for Philosophy in the Analytic Tradition, vol. 135, $\mathrm{n}^{\circ}$ 1, August 2007, pp. 1-15; The Philosophy of Moving Pictures, Malden, MA, Blackwell, 2008, chap. 5, section 2, "Cinematic Narration," pp. 133-46; "Narrative closure," Paisley Livingston and Carl Plantinga (ed.), The Routledge Companion to Philosophy and Film, Londres, Routledge, 2009, chap. 19, pp. 207-216; Art in three dimensions, chap. 17, "Narrative closure," New York, Oxford University Press, 2010, pp. 355-72.

3. Carroll, "Narrative closure," Philosophical Studies, p. 1.

4. Carroll, "Narrative closure," Routledge Companion, p. 207; Art in three dimensions, p. 367.

5. Carroll, "On Narrative Connection," Beyond Aesthetics, Cambridge, Cambridge University Press, 2001, p. 127; Art in three dimensions, p. 367.

6. Vsevolod I. Poudovkine, Film Technique in Film Technique and Film Acting, New York, Grove Press, 1958, pp. 73; 77.

7. Carroll, "Toward a Theory of Film Suspense," Theorizing the Moving Picture, p. 96.

8. Carroll, "Narrative Closure," Routledge Companion, p. 213 ; Art in three dimensions, p. 366.

9. See, for example, Richard Davies, "Lost in Lost's Time," in The Ultimate Lost and Philosophy: Think Together, Die Alone, ed. Sharon Kaye, Hoboken, New Jersey, John Wiley \& Sons, Inc., 2011, pp. 9-31.

10. Carroll, "Narrative Closure," The Routledge Companion, p. 213 ; Art in three dimensions, p. 366. In recent times, the example of the outrage created by the cliffhanger at the end of the last episode of season 6 of The Walking Dead (F. Darabont and R. Kirkman, AMC, 2010-) is a good example of this. The authors even went so far as to apologize to fans for not having revealed the identity of Negan's victim, which was in contradiction with what was promised by the teasers aired by AMC before the release of that season. For a sampling of reactions gleaned off the internet, see https://goo.gl/fwMemF (consulted May 26, 2016). 
11. "Okay, that thing in the woods, maybe it's a monster, maybe it's a pissed-off giraffe, I don't know. The fact that no one is even looking for us-yeah, that's weird. But I just go along with it... 'cause I'm along for the ride-good old fun-time Hurley. Well, guess what-now, I want some freakin' answers!"

12. J. David Velleman, "Narrative Explanation," The Philosophical Review, vol. 112, $\mathrm{n}^{\circ}$ 1, January 2003, pp. 1-25.

13. In this vein, George M. Wilson writes that, "The dramatically significant questions that a narrative fiction film can raise about its characters are effectively unlimited." See also George M. Wilson, Narration in Light, Baltimore, John Hopkins University Press, 1986, p. 50.

14. Carroll's example is problematic. We can watch the film and understand it without being frustrated by the fact that it represents primarily the older brother's perspective.

15. See also David Auerbach's comments in "The Cosmology of Serialized Television," The American Reader, June 2013, http://theamericanreader.com/the-cosmology-of-serializedtelevision/ (consulted May 25, 2016).

16. In a striking visual illustration of the pact of submission in Thomas Hobbes's Leviathan.

17. Aristotle, ed. Hugh Lawson-Tancred. Metaphysics, VII, Penguin Books, 2004.

18. Carroll, "Toward a Theory of Film Suspense," p. 98.

19. Carroll, Beyond Aesthetics. Philosophical Essays, Cambridge, Cambridge University Press, 2001, pp. 118-133.

20. This is more or less Davies's conclusion in his article on the conceptual problems posed by the idea of time travel: As long as the screenwriters do their job, which consists in helping us to avoid dwelling on these contradictions and suggesting instead that we look for answers to the questions related to what the characters are experiencing, we can obtain a sense of satisfaction and pleasure from watching the series. Richard Davies, "Lost in Lost's Time," pp. 29-30.

21. See also Pacome Thiellement, Les mêmes yeux que Lost, Paris, Léo Scheer, 2011.

22. Pacome Thiellement on Lost at the Forum des images, April 20, 2012, in the context of the festival "Séries mania": http://goo.gl/I3rSbW (consulted May 25, 2016).

23. For more on the importance of Descartes's text, see also Denis Moreau, Dans le milieu d'une forêt. Essai sur Descartes et le sens de la vie, Paris, Bayard, 2012.

24. See also Hugo Clémot, "Une lecture des films d'horreur épidémique," Tracés, "Contagions," compiled by Florent Coste, Aurélien Robert, and Adrien Minard, n²1, 2011/2, pp. 167-184, http://traces.revues.org/5209 (consulted May 25, 2016).

25. The many hallucinatory experiences and dreams function as examples of the skeptic argument of the Cartesian dream. See also Sarah Hatchuel, Lost: Fiction vitale, Paris, Presses universitaires de France, 2013, p. 52.

26. Hatchuel, p. 30.

27. Saül Kripke, Wittgenstein on Rules and Private Language: An Elementary Exposition, Harvard University Press, Cambridge, Mass., 1982.

28. Idem, p. 60 .

29. Wittgenstein, Ludwig, et al. Philosophical Investigations. Translated by G.E.M. Aniscombe, 4th ed., Wiley-Blackwell, 2010, p. 87e.

30. See the episode "Numbers" (S01E18).

31. It is worth reflecting on the curious reversal that the series paradox could produce in relation to questions surrounding the connection between cinema and existentialism. Indeed, in the article "Sartre's cinema," Pascale Fautrier teaches us that "it was in a 1931 text on cinema that this major opposition in Sartrian reflection between art and the contingency of existence was formulated for the first time; and it was formulated about cinema." she cites Sartre's illuminating remarks in his filmed interview in 1972, which would later become the film Sartre par lui-même (Sartre According to Himself), directed by Alexandre Astruc, Michel Contat, and Guy Séligmann, 1976 : "I know that the idea of contingency came from the comparison that 
established itself spontaneously in my mind between the landscape of a film and the landscape of reality. With the landscape of a film, the director makes it so that there is a certain unity and a precise relationship to the character's emotions. Whereas there is no unity in the landscape of reality. There is a unity of randomness that really struck me. And the other thing that really struck me is that the objects in film had a precise role to fill, a role linked with the character, whereas in reality, objects exist by chance," quoted from Jean-Paul Sartre, Euvres romanesques, Gallimard, Bibliothèque de la Pléiade, p. 1698 (my translation). See also, Pascale Fautrier, "Le cinéma de Sartre" (Sartre's cinema), Fabula-LhT, nº 2 , "Ce que le cinéma fait à la littérature (et réciproquement)" (That which cinema does to literature (and vice versa)), December 2006, http://www.fabula.org/lht/2/fautrier.html (consulted May 25, 2016).

32. Roz Kaveney, "She saved the world. A lot. An introduction to the themes and structures of Buffy and Angel," Reading the Vampire Slayer: The Complete, Unofficial Guide to Buffy and Angel, New York, I.B. Tauris, 2004, p. 10.

33. See also Sandra Laugier, "Vertus ordinaires des cultures populaires," Critique, $\mathrm{n}^{\circ}$ 776-777, January-February 2012, pp. 48-61.

34. See also Michelle A. Lang, "Lost: Poststructural Metanarrative or Postmodern Bildungsroman?" (2007), LOST Thought. Leading Thinkers Discuss LOST, ed. Pearson Moore, Vancouver, Inukshuk Press, 2012, p. 308 : "Suddenly torn from their usual lives, they have plenty of time, and stimuli, on the island to provoke a meditation on who they really are and how they got to this point, on core beliefs that no longer seem valid, and on maps of the world inherited from family systems that now need to be redrawn."

35. Kant, Emmanuel, Critique of Judgement, Translated by Werner S. Pluhar, Hackett, 2010, p. 413.

36. Cavell, John Gibson Wolfgang Huemer (ed.), The Literary Wittgenstein, Routledge, 2004, pp. 21-33.

37. Cavell, Stanley, "Music Discomposed," Must We Mean What We Say ? A Book of Essays, Cambridge, Cambridge University Press, 1998, p. 198.

38. Cavell, Stanley "Being Odd, Getting Even: Threats to Individuality », Salmagundi: A Quarterely of the Humanities and Social Sciences, 67, 1985, p. 127.

39. See also Hatchuel, p. 90.

40. Cavell, "L'évitement de l'amour," DVD, p. 483.

41. Cavell, loc. cit. See especially "Connaître et reconnaître," DVD, pp. 377-412.

42. Cavell, Stanley, "The Avoidance of Love", Must We Mean What We Say ? A Book of Essays, Cambridge University Press, 1998, p. 325.

43. See also Hatchuel, pp. 74-75: "Through these flashes, the survivors reflect on their own emotions and, little by little, free themselves from their own personal prisons... which allows their moralities to evolve." (My translation)

44. Serge Tisseron, Comment Hitchcock m'a guéri. Que cherchons-nous dans les images ? Paris, Pluriel, 2014 (2003), p. 79.

45. Sándor Ferenczi, "Analyse d'enfants avec des adultes," Psychanalyse, t. 4, Paris, Payot, 1982 (1931), p. 106. (My translation)

46. Tisseron, p. 84.

47. Jean-Pierre Esquenazi, La vérité de la fiction, Paris, Lavoisier, 2009, p. 155. (My translation.)

48. Cavell, The World Viewed. Reflections on the Ontology of Film, Enlarged Edition, Cambridge, Massachusetts and London, England, Harvard University Press, 1979, p. 115. See also Hugo Clémot, La Philosophie d'après le cinéma. Une lecture de La Projection du monde de Stanley Cavell, Rennes, Presses universitaires de Rennes, 2014, pp. 163-176.

49. Idem p. 161.

50. Tisseron, Comment Hitchcock m'a guéri, p. 84. (My translation.)

51. Arthur Danto, L'assujettissement philosophique de l'art, Paris, Seuil, 1993 (1986). 


\section{ABSTRACTS}

That the viewers of the Lost TV series were so disappointed by its last episode has something to do with the philosophical problem of narrative closure. To resolve this conceptual difficulty, Noel Carroll has conceived an 'erotetic' model in which the impression of finality someone usually feels at the end of most films and TV episodes is due to the fact that the questions the viewers ask themselves in the course of following the plot finally get an answer. This theory thus seeks to explain not only the enthusiasm which the TV series succeeds in eliciting by intriguing viewers with accumulating mysteries, but also how the viewers feel let down in the end when they realize they have not been given all the keys to solve these mysteries. This erotetic model surely has at least a formal interest. One, however, has reasons to prefer, and reasons that can be found in Lost, a teleological model where the relations between questions and answers are better understood when we see them as a question of the relation between means and ends. Yet this teleological model presupposes that we can somehow know the goals of the characters and of the narrative. If that were not the case, nothing would make sense, indeed. Still we can only acknowledge our separateness from the characters and from the projected world and admit that we have no choice but to understand without being certain that we are not simply projecting goals that do not exist outside of our minds. TV series allow us to live a skeptical experience, which originates in what can be called the 'series-following paradox' which is that we could always choose to follow a numerical series or a TV series and to retrospectively modify the meaning of the numbers or past events which constitute it. This skeptical truth not only threatens the TV experience we undergo while watching our favorite shows, but it also affects our perception of the meaning of our own personal lives. It also gives us a chance to change and to reach a better self. In order to surmount this skeptical trial, the Lost TV series teaches us to contemplate the form of a finality which seems to design life, without being able to get a representation of its goal, a lesson which actually enables us to see the ending of Lost as a success.

La question de savoir pourquoi tant de spectateurs furent si déçus par la fin de Lost pose le problème de la clôture narrative. Pour le résoudre, Noël Carroll a proposé un modèle "érotétique ", qui soutient que l'impression de finalité que l'on ressent à la fin de la plupart des films et des épisodes est provoquée par le fait que les questions que se pose le spectateur trouvent finalement une réponse. Cette théorie expliquerait l'enthousiasme suscité par une série qui accumule les mystères, mais aussi la déception finale de ne pas avoir reçu toutes les clés pour les comprendre. Si ce modèle érotétique présente incontestablement un intérêt au moins formel, on peut montrer, à partir de Lost, qu'il est néanmoins préférable de penser les choses selon un modèle téléologique où la subordination de certaines questions et réponses à d'autres renvoie en fait à un rapport entre moyens et fins. Cependant, on présuppose alors qu'il doit être possible de connaître les fins des personnages et du récit, sans quoi rien n'aurait de sens, alors que nous ne pouvons que reconnaître le caractère séparé des personnages et du monde projeté, et admettre que nous sommes condamnés à comprendre sans jamais être certains que nous ne fassions pas que projeter des fins qui ne s'y trouvent pas. Or, les séries télévisées permettent de vivre une expérience sceptique, créée par ce que l'on peut appeler le "paradoxe des séries ", c'est-à-dire l'idée qu'il est toujours possible de poursuivre une série autrement et de modifier ainsi rétrospectivement le sens des nombres ou des événements passés qui la constituent, une vérité sceptique qui menace aussi l'histoire personnelle du spectateur, tout en lui offrant la possibilité de changer et d'atteindre un meilleur état du moi. Pour surmonter cette épreuve sceptique, la série nous apprend à contempler la forme d'une finalité qui semble se dessiner dans toute vie, 
sans qu'on puisse se former une représentation de sa fin, une leçon qui justifie que l'on puisse trouver la fin de Lost réussie.

\section{INDEX}

Mots-clés: Lost, clôture, narration, Carroll Noël, modèle érotétique, modèle téléologique, paradoxe des séries, expérience esthétique

Keywords: Lost, closure, Carroll Noël, erotetic model, teleological model, parodox of series, aesthetic experience

\section{AUTHORS}

\section{HUGO CLÉMOT}

Hugo Clémot, laureate of the agrégation, holds a $\mathrm{PhD}$ in philosophy and teaches at the university of Tours. A specialist of the philosophy of cinema and a member of the "Centre de philosophie contemporaine de la Sorbonne", he is the author of the following books: Les Jeux philosophiques de la trilogie Matrix (Vrin, 2011), La Philosophie d'après le cinéma (PUR, 2014) and Enseigner la philosophie avec le cinéma (ed., Les Contemporains favoris, 2015). He aims at making philosophical (post)analyses of cinema more accessible and at creating a philosophy of TV series.

Hugo Clémot est agrégé, docteur en philosophie et chargé de cours à l'Université de Tours. Spécialiste de philosophie du cinéma, associé au Centre de philosophie contemporaine de la Sorbonne (ISJPS), il a publié les ouvrages : Les Jeux philosophiques de la trilogie Matrix (Vrin, 2011), La Philosophie d'après le cinéma (PUR, 2014) et Enseigner la philosophie avec le cinéma (dir., Les Contemporains favoris, 2015). CEuvrant par ses articles et ses interventions à la diffusion des philosophies analytiques et post-analytiques du cinéma, il cherche aussi à contribuer à la création d'une philosophie des séries télévisées. 